Jurnal Ilmu Dan Teknologi Kesehatan

Vol 7, No 1, September 2019,

ISSN: 2338-9095 (Print)

ISSN: 2338-9109 (online)

\title{
Identifikasi Aspergillus fumigatus pada Sputum Pasien Suspek TB Paru
}

\author{
Angriani Fusvita, Firdayanti, Sri Yosin Vinola \\ Politeknik Bina Husada Kendari \\ Email:angrianif@gmail.com
}

\author{
Artikel history \\ Dikirim, Agust $9^{\text {th }}, 2019$ \\ Ditinjau, Agust 20 2019 \\ Diterima, Sept $10^{\text {th }}, 2019$
}

\begin{abstract}
Tuberculosis (TB) is a contagious infectious disease caused by the Mycobacterium tuberculosis, which can attack various organs especially the lungs. In some cases, there is a misdiagnosis between pulmonary tuberculosis and pulmonary mycosis (lung fungus). One of the species of fungus that often causing infection in the lungs is Aspergillus fumigatus.This study aims to identify Aspergillus fumigatus in sputum patients suspected of pulmonary tuberculosis patients at General Hospital in Baubau City. The types of research is descriptive with accidental sampling technique. Research was carried out by examining the BTA status of patients using the GeneXpert device and the patients sputum were isolated into Potato Dextrose Agar (PDA) medium then examined in macroscopic and microscopic (slide culture). Result of the study of 27 samples sputum patients suspected of pulmonary tuberculosis in Baubau Town Hospital obtained patients who infected Aspergillus fumigatus fungus amounted to 3 people with 2 including identified fungi with positive BTA status. Conclusion patients infected with Aspergillus fumigatus amounted to 3 people (7.4\%) and 2 people (3.4\%) identified fungi with positive pulmonary tuberculosis.
\end{abstract}

Keywords: Pulmonary Tuberculosis Suspect; Aspergillus fumigates; Sputum

\begin{abstract}
ABSTRAK
Tuberkulosis (TB) adalah suatu penyakit infeksi menular yang disebabkan oleh bakteri Mycobacterium tuberculosis, yang dapat menyerang berbagai organ terutama paru-paru. Dalam beberapa kasus, terjadi kesalahan diagnosis antara Tuberkulosis paru dan mikosis paru (jamur paru). Salah satu spesies jamur yang sering menyebabkan infeksi pada paru-paru adalah Aspergillus fumigatus. Penelitian ini bertujuan untuk mengidentifikasi jamur Aspergillus fumigatus pada sputum pasien suspek TB Paru di RSUD Kota Baubau. Jenis penelitian ini adalah deskriptif dengan teknik pengambilan sampel secara accidental sampling. Penelitian dilakukan dengan memeriksa status BTA pasien menggunakan alat GeneXpert dan sputum pasien diisolasi ke dalam media Potato Dextrose Agar (PDA) kemudian selanjutnya dilakukan pemeriksaan secara makroskopis dan mikroskopis (slide culture). Hasil penelitian terhadap 27 sampel sputum pasien suspek TB paru di RSUD Kota Baubau diperoleh 3 pasien (7.4\%) yang terinfeksi jamur Aspergillus fumigatus dengan 2 (3.4\%) diantaranya teridentifikasi jamur dengan status BTA positif. Kesimpulan pasien yang
\end{abstract}


terinfeksi jamur Aspergillus fumigatus berjumlah 3 orang dan 2 orang teridentifikasi jamur dengan TB paru positif.

Kata Kunci: Suspek Tuberkulosis Paru; Aspergillus fumigatus; Sputum

\section{PENDAHULUAN}

Tuberkulosis (TB) adalah suatu infeksi akut atau kronis yang disebabkan oleh bakteri Mycobacterium tuberculosis, yang dapat menyerang berbagai organ terutama paru-paru (Kelly et al. 2009). TB adalah salah satu dari 10 penyebab utama kematian di seluruh dunia (WHO, 2018). Secara global pada tahun 2016 terdapat 10,4 juta kasus insiden TB yang setara dengan 120 kasus per 100.000 penduduk. Lima negara dengan insiden kasus tertinggi yaitu India, Indonesia, China, Philipina, dan Pakistan (WHO, 2018). Jumlah kasus baru TB di Indonesia sebanyak 420.994 kasus pada tahun 2017 (Kemenkes RI, 2018). Pada tahun 2017 di Sulawesi Tenggara ditemukan 2.587 kasus baru BTA positif (BTA+), menurun dibandingkan tahun 2016 dengan jumlah 3.105 kasus. Kota Baubau di urutan keempat dengan 228 kasus baru BTA positif (Dinkes Prov Sultra, 2018).

Pada beberapa kasus, terjadi kesalahan diagnosis antara Tuberkulosis paru dan mikosis paru. Hal ini terjadi karena kurangnya gejala klinis patognomonis dan karakteristik radiologi yang khas untuk penyakit ini sert tidak memadainya fasilitas pemeriksaan di laboratorium mikologi. Jamur saprofit memiliki luas distribusi di alam dan spora yang berlimpah di udara dan penularan infeksi terjadi dengan dihirup (Hedayati et al. 2010). Penggunaan ekstensif antibiotik dan steroid juga menyebabkan prevalensi luas dari infeksi mikosis paru. Beberapa faktor seperti defisiensi imun, penyakit kronis, keganasan terlibat dalam memperburuk penyakit ini. Infeksi mikosis paru dapat dibentuk primer dan sekunder pada infeksi TB (Osman et al, 2013). Pada banyak kasus infeksi mikosis paru karena kurangnya manifestasi klinis spesifik menyebabkan tingkat morbiditas dan mortalitas yang tinggi (Pfaller dan Diekema, 2007). Salah satu jamur penyebab mikosis paru yaitu Aspergillus fumigatus. A.fumigatus adalah penyebab infeksi ganas pada paru-paru pasien yang terkena TB paru (Bansod dan Rai, 2008). Penelitian yang telah dilakukan menggunakan 51 sampel sputum penderita batuk kronik yang berasal dari Rumah Sakit Haji Adam Malik Medan menunjukkan hasil kultur A.fumigatus 
positif 29 sampel (57\%) dan kultur negatif 22 sampel (43\%) (Thristy dan Siregar, 2016).

\section{METODE}

Desain penelitian yang dilakukan adalah Deskriptif Cross sectional yaitu penelitian yang dilakukan dengan mengamati objek dan melakukan pengukuran variabel penelitian pada satu waktu. Populasi dari penelitian ini adalah pasien suspek TB paru yang memeriksakan sputumnya di Laboratorium RSUD Kota Baubau dengan menggunakan metode Accidental sampling. Berikut ini merupakan prosedur penelitian yang dilakukan:

a. Persiapan Sampel

Pada pengambilan sampel berupa sputum, diminta kepada pasien agar mengeluarkan sputum ke dalam pot sputum steril dan kemudian pot sputum ditutup dengan rapat dan diberi label identitas pasien.

b. Penyiapan Media

Media PDA ditimbang $20 \mathrm{~g}$ dan dilarutkan dalam aquadest $500 \mathrm{~mL}$. Kemudian dipanaskan sampai mendidih sambil diaduk agar merata, lalu disterilkan. Biarkan media hingga suhu $\pm 50^{\circ} \mathrm{C}$ lalu ditambahkan antibiotic Chloramphenicol $500 \mathrm{mg}$.

c. SterilisasiAlat
Sterilisasi kering (oven) pada suhu $180^{\circ} \mathrm{C}$ selama 1 jam untuk alat-alat seperti cawan petri, tabung reaksi dibersihkan dan dikeringkan dan sterilisasi uap panas bertekanan (autoklave) untuk media Potato Desktrosa Agar (PDA) pada suhu $121^{\circ} \mathrm{C}$ selama 15 menit.

d. Pemeriksaan Sampel

Sampel sebanyak 27 pasien suspek TB dilakukan pewarnaan Basil Tahan Asam dan dilanjutkan secara molekuler menggunakan alat GeneXpert

e. Pemeriksaan Aspergillus fumigatus secara makroskopis

Diambil sputum menggunakan ose bulat kemudian diisolasi ke media PDA dengan metode tuang (Pour Plate). Diinkubasi pada suhu $\pm 25^{\circ} \mathrm{C}$ selama 3-5 hari dan diamati koloni yang tumbuh secara makroskopis.

f. Pemeriksaan Aspergillus fumigatus secara mikroskopis (slide culture method)

Disiapkan jamur yang sudah diisolasi. Dipotong media PDA membentuk dadu. Diambil satu potongan media yang berbentuk dadu kemudian diletakkan pada kaca objek dalam cawan petri dengan metode slide culture, lalu ditutup dengan kaca penutup. Diambil koloni jamur dengan 
menggunakan ose lurus. Kemudian diinokulasikan pada sisi samping media PDA dalam cawan. Diinkubasi selama 3-5 hari dengan suhu $\pm 25^{\circ} \mathrm{C}$. Setelah diinkubasi, diambil kaca objek dari cawan lalu diberi pewarnaan
Lactophenol Cotton Blue kemudian diamati menggunakan mikroskop.

\section{HASIL DAN PEMBAHASAN}

Berdasarkan hasil penelitian yang telah dilakukan dengan pemeriksaan pada sputum pasien suspek TB (Tuberkulosis), maka diperoleh hasil sebagai berikut:

Tabel 1. Distribusi hasil pemeriksaan BTA pada sputum menurut jenis kelamin

\begin{tabular}{ccc}
\hline \multirow{2}{*}{ Jenis Kelamin } & \multicolumn{2}{c}{ Hasil Identifikasi BTA } \\
\cline { 2 - 3 } & Positif & Negatif \\
\hline Laki-Laki & $13(48.1 \%)$ & $2(7.4 \%)$ \\
Perempuan & $7(25.9 \%)$ & $5(18.5 \%)$ \\
\hline Jumlah & $20(74 \%)$ & $7(26 \%)$ \\
\hline
\end{tabular}

Tabel 1 tentang distribusi hasil pemeriksaan BTA pada sputum pasien suspek TB Paru di RSUD Kota Baubau menurut jenis kelamin menunjukkan bahwa pasien yang terinfeksi TB Paru lebih banyak berjenis kelamin laki-laki yaitu sebanyak 13 pasien dan perempuan sebanyak 7 orang. Menurut Neyrolles dan Quintana (2009), pria cenderung lebih berisiko untuk menderita TB Paru dibanding wanita. Alasan pasti mengenai hal ini belum diketahui, namun hal ini diduga terkait dengan hormon Estradiol pada wanita yang berfungsi meningkatkan respon imunitas selular melalui aktivasi makrofag oleh IFN-gamma yang menyebabkan wanita memiliki ketahanan lebih dalam melawan tuberkulosis dibandingkan pria. Menurut Kemenkes RI (2018) menyatakan hal ini terjadi kemungkinan karena laki-laki lebih terpapar pada faktor risiko TB misalnya merokok dan kurangnya ketidakpatuhan minum obat. Survei ini menemukan bahwa dari seluruh partisipan laki-laki yang merokok sebanyak 68,5\% dan hanya 3,7\% partisipan perempuan yang merokok. 
Tabel 2. Distribusi hasil pemeriksaan BTA pada sputum berdasarkan Kelompok Umur

\begin{tabular}{ccc}
\hline \multirow{2}{*}{ Umur } & \multicolumn{2}{c}{ Hasil Identifikasi BTA } \\
\cline { 2 - 3 } & Positif & Negatif \\
\hline 11-20 Tahun & $1(3.7 \%)$ & $0(0 \%)$ \\
21-30 Tahun & $9(33.3 \%)$ & $0(0 \%)$ \\
31-40 Tahun & $8(29.6 \%)$ & $0(0 \%)$ \\
41-50 Tahun & $0(0 \%)$ & $1(3.7 \%)$ \\
51-60 Tahun & $2(7.4 \%)$ & $2(7.4 \%)$ \\
61-70 Tahun & $0(0 \%)$ & $3(11.1 \%)$ \\
71-80 Tahun & $0(0 \%)$ & $1(3.7 \%)$ \\
\hline Jumlah & $20(74 \%)$ & $7(26 \%)$ \\
\hline
\end{tabular}

Tabel 2 menunjukkan bahwa distribusi hasil pemeriksaan BTA pada sputum pasien suspek TB Paru di RSUD Kota Baubau berdasarkan kelompok umur diperoleh kelompok umur pasien yang positif terinfeksi TB Paru tertinggi terdapat pada kelompok umur 21-30 tahun yaitu sebanyak 9 pasien. Sedangkan hasil negatif ditemukan pada kelompok umur 41- 50 tahun, 61-70 tahun dan 71-80 tahun.

Tabel 3. Distribusi hasil pemeriksaan BTA pada sputum pasien suspek TB Paru

\begin{tabular}{ccc}
\hline Hasil BTA & Frekuensi (n) & Persentase (\%) \\
\hline Negatif (-) & 7 & 25.9 \\
Positif (+) & 16 & 59.2 \\
Positif (++) & 3 & 11.1 \\
Positif (+++) & 1 & 3.7 \\
\hline Jumlah & 27 & 100 \\
\hline
\end{tabular}

Tabel 3 menunjukkan bahwa dari 27 sampel sputum yang digunakan dalam penelitian, 20 sputum BTA positif, di mana masing-masing sputum positif (+), positif (++), dan positif (+++). Sedangkan yang tidak terdeteksi pada pemeriksaan BTA secara molekuler (GeneXpert) sebanyak 7 sputum BTA negatif (-). 
Tabel 4. Distribusi hasil pemeriksaan identifikasi jamur pada sputum berdasarkan Status BTA

\begin{tabular}{ccc}
\hline \multirow{2}{*}{ Status BTA } & \multicolumn{2}{c}{ Hasil Identifikasi } \\
& \multicolumn{1}{c}{ Aspergillus } & fumigatus \\
\cline { 2 - 3 } & Positif & Negatif \\
\hline BTA Positif & $2(7.4 \%)$ & $17(62.9 \%)$ \\
BTA Negatif & $1(3.7 \%)$ & $7(25.9 \%)$ \\
\hline Jumlah & $3(11.1 \%)$ & $24(88.8 \%)$ \\
\hline
\end{tabular}

Tabel 4 menunjukkan bahwa distribusi mikosis paru oportunistik akibat pasien suspek TB Paru di RSUD Kota mekanisme pertahanan tubuh yang Baubau menurut status BTA diperoleh terganggu. Menurut Buthia dan Adhikari sebanyak $7.4 \%$ teridentifikasi jamur (2015) mikosis paru sering salah dengan status BTA positif, sedangkan didiagnosis sebagai Tuberkulosis (TB) sebanyak $3.7 \%$ teridentifikasi Aspergillus karena gejala klinis patognomonis dari fumigatus dengan status BTA negatif. penyakit ini tidak diketahui dan tidak Pada penelitian yang dilakukan oleh Sukamto (2011) terkait dengan adanya karakteristik radiologi yang khas. Hal ini menyebabkan pasien dengan gejala pemeriksaan jamur bilasan bronkus pada serupa TB Paru berupa batuk lebih dari 2 penderita bekas tuberkulosis paru minggu, sering dirujuk untuk pemeriksaan menunjukkan pasien suspek TB Paru yang positif tuberkulosis dapat mengalami lanjutan ke rumah sakit dengan diagnosis terduga

TB.

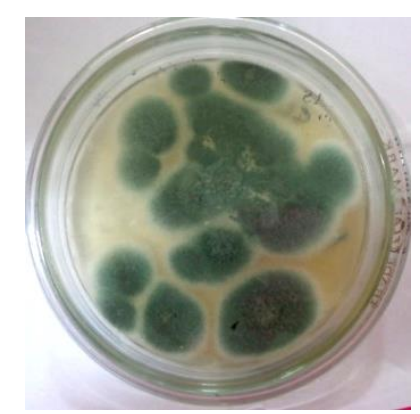

(a)

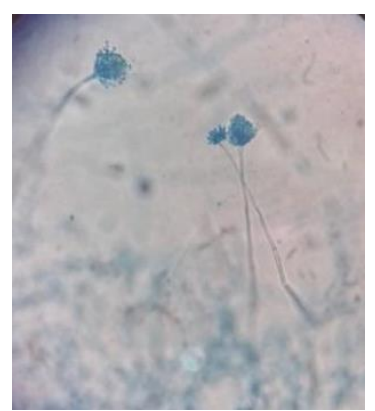

(b)

Gambar a. Pengamatan makroskopis koloni Aspergillus fumigatus;

b. Pengamatan mikroskopis Aspergillus fumigatus

Penemuan jamur pada sputum yang tertera pada Gambar 1 menunjukkan hasil pengamatan

makroskopis

koloni Aspergillus fumigatus ditemukan 
pertumbuhan filament putih yang kemudian akan memproduksi spora seperti beludru dengan warna putih keabu-abuan seiring dengan lamanya waktu inkubasi. Pada pemeriksaan mikroskopis menggunakan mikrokop ditemukan adanya ciri-ciri antara lain memiliki hifa hialin bersepta (konidiospora) dan membentuk konidia (spora). Kepala konidia berbentuk bulat hingga oval. Penelitian yang dilakukan oleh Kalyani et al. (2016), Yaduet al. (2015) dan Ekenna, et al. (2007) menunjukkan hasil yang serupa di mana jamur filamentus yang paling banyak terisolasi dari sputum pasien TB paru adalah Aspergillu ssp. Selain itu, Osman et al. (2013) dalam penelitiannya terkait dengan deteksi mikroarray dari infeksi jamur pada pasien TB paru menunjukkan spesies Aspergillus sp. adalah satu-satunya jamur yang terdeteksi dalam 24\% kasus dengan spesies dominan yaitu Aspergillus fumigatus.

Dalam kehidupan sehari-hari manusia dapat menghirup konidia Aspergillus fumigatus yang tersebar bebas di udara. Hal inilah yang menyebabkan Aspergillus fumigatus menjadi salah satu jamur yang paling sering ditemukan di isolat saluran nafas. Pada orang imunokompeten, konidia ini akan dapat dieliminasi secara efektif tanpa menimbulkan gangguan kesehatan. Penemuan Aspergillus fumigatus pada individu yang tidak menunjukkan gejala penyakit, dianggap sebagai kolonisasi dan bukan infeksi. Aspergillus dapat menimbulkan berbagai reaksi infeksi dan alergi pada pasien dengan keadaan immunocompromised. Hal ini sesuai dengan penelitian Kousha et al.(2011) yang menunjukkan angka kejadian penyakit ini meningkat secara signifikan seiring dengan meningkatnya jumlah pasien dengan keadaan sistem imun tubuh yang lemah.

\section{SIMPULAN}

Berdasarkan hasil penelitian yang telah dilakukan maka dapat disimpulkan bahwa pasien dengan status BTA positif sebanyak 20 orang, pasien yang paling banyak terinfeksi TB Paru adalah laki-laki yaitu sebanyak 13 pasien, dan kelompok umur tertinggi terdapat pada usia 20-30 tahun yaitu sebanyak 9 pasien. Pasien yang terinfeksi jamur Aspergillus fumigatus berjumlah 3 orang (7.4\%) dengan 2 (3.4\%) diantaranya teridentifikasi jamur dengan status BTA positif.

\section{DAFTAR RUJUKAN}

Buthia, T. and Adhikari, L. 2015. Pulmonary mycoses among the clinically suspected cases of pulmonary tuberculosis. International 
Journal of Research in Medical Sciences, 3(1), 260-268.

Bansod S, Rai M. 2008. Emerging of mycotic infection in patients infected with Mycobacterium tuberculosis. World J Med Sci.3(2):74-80.

Dinas Kesehatan Provinsi Sulawesi Tenggara. 2018. Profil Kesehatan Provinsi Sulawesi Tenggara Tahun $2017 . \quad$ Diakses2Juli 2019http://www.depkes.go.id/resource s/download/profil/PROFIL_KES_PRO VINSI_2017/28_Sultra_2017.pdf.

Ekenna O., Uba A., Chikwern JO., Mambula S., Aliyu MB., Mohammed I. 2007. Relevance of Moldy Fungi as Agents of Chronic Lower Respiration Tract Infection in Patients Seen in Maiduguri, Nigeria. West Afr J Med. 26 (2), 117-200.

Hedayati MT, Mayahi S, Denning DW. 2010. A study on Aspergillus species in houses of asthmatic patients from Sari City, Iran and a brief review of the health effects of exposure to indoor Aspergillus. Environ Monit Assess.;168(14):481-7.

Neyrolles, O. and Quintana-Murci, L. 2009. Sexual Inequality in Tuberculosis. PLoS Medicine, 6(12), 16.

http://doi.org/10.1371/journal.pmed.10 $\underline{00199}$

Kalyani CS., Koripella RM., Madhu Ch. 2016. Fungal Isolates in Sputum Samples of Multidrug-resistant Tuberculosis Suspects. International Journal of Scientific Study. 4(2): 164166.

Kousha, M., Tadi, R. and Soubani, AO. 2011. Pulmonaryaspergillosis: a clinical review. European Respiratory Review. 20(121): 156-174.

Kelly H, Bennet N, Murray S, O’Grady KA. 2009. 73 Penyakit yang penting diketahui. Yogyakarta: Pallmall Yogyakarta.

[Kemenkes RI] Kementerian Kesehatan Republik Indonesia. 2019. Data dan Informasi Profil Kesehatan Indonesia 2018.

http://www.depkes.go.id/download.ph p?file $=$ download/pusdatin/infodatin/inf odatin\%20tuberkulosis\%202018.pdf.

Osman NM, Gomaa AA, Sayed NM. 2013. Microarray detection of fungal infection in pulmonary tuberculosis. Egypt J Chest Dis;62(1):151-7

Pfaller M, Diekema D. 2007. Epidemiology of invasive candidiasis: a persistent public health problem. Clin Microbiol Rev ,20(1):133-163.

Sukamto. 2011. Pemeriksaan Jamur Bilasan Bronkus pada Penderita Bekas Tuberkulosis Paru. Medan: Universitas Sumatera Utara

Thristy I, Siregar Y. 2016. Aspergillus Fumigatus pada Sputum Penderita Batuk Kronik Menggunakan Metode PCR dan Kultur. $M K B$,48(2):78-83.

\section{[WHO] World Health Organization. $2018 . \quad$ Tuberculosis. http://www.who.int/news-room/fact- sheets/detail/tuberculosis.}

Yadu R, Nawange RR, Singh SM, Gutch RS, Gumasta R, Nawange M. J. 2015. Prevalence of Opportunistic Fungal Pathogens in Pulmonary Tuberculosis Patient from Madhya Pradesh, Central India. J Microbiol Biomed. 1(6): 1-12. 